\title{
Tradesman: Skilled Specialist or Manager?
}

Artisan, de l'homme de métier au gestionnaire?

\section{Caroline Mazaud}

\section{(2) OpenEdition}

\section{Journals}

\section{Electronic version}

URL: http://journals.openedition.org/travailemploi/6297

DOI: 10.4000/travailemploi.6297

ISSN: 1775-416X

\section{Publisher}

DARES - Ministère du Travail

\section{Printed version}

Date of publication: 15 December 2013

Number of pages: $71-82$

ISSN: 0224-4365

\section{Electronic reference}

Caroline Mazaud, «Tradesman: Skilled Specialist or Manager? », Travail et Emploi [Online], Horssérie | 2013, Online since 01 January 2014, connection on 01 May 2019. URL : http:// journals.openedition.org/travailemploi/6297 ; DOI : 10.4000/travailemploi.6297 


\title{
Tradesman: Skilled Specialist or Manager?"
}

\author{
Caroline Mazaud ${ }^{(* *}$
}

The ideal-type of the division of labor in the trades is based on age groups, implying a shared practice of the trade and the mastery of the entire fabrication process by everyone in the workshop, be they employees or the boss. They all follow the same socio-professional progression: sharing a norm for the knowledge acquisition process, they subscribe to the same model of social success that culminates in setting themselves up in business. This unites them in a sort of mirror of identification, which is the basis of relations within a trade. The reality observed today, though, is distancing itself from this model. Since the 1980s legislative and institutional contexts have transformed, expanding the boundaries of what a trade business may be and lowering the barrier for starting one, thus redefining the division of labor in the trades. Comparing "departures" from and "arrivals" to the trades, we observe a tendency to separate management and productive activities, which reduces the shared practice of the trade between employees and employers. Additionally, tradespeople come from a wider range of backgrounds, leading to the coexistence of varied socio-professional career histories. Today the trades, once a pathway for social promotion for workers, have also become a safety net for career-changers from the middle class.

"The trades, France's number one business": the media-saturating refrain of the National Fund for the Promotion and Communication of the Trades (FNPCA). ${ }^{(1)}$ Its current policy to improve the general public's image of the trades joins the concerns of public authorities trying to reduce unemployment through business creation and hiring incentives. These principles result in a series of measures to facilitate official procedures favoring independent business ownership and lighten employers' social tax contributions, if not exonerate them entirely. Although the French situation has its particularities stemming from historical factors and the national legislative framework, this active policy has concerned all member states of the European Union since the 1980s. It was ratified by European Union leadership in Lisbon in 2000, when the framework for the Union's future development was outlined. Such a policy can first be explained by the economic crisis: when growth slows, it is difficult to lower unemployment. Heavy industry is also in crisis, which prompts governments to look to the potential of small business (BOUTILLIER, 2007).

(*) Article published in French in Travail et emploi, $\mathrm{n}^{\circ}$ 130, avril-juin 2012.

(**) Centre nantais de sociologie (Nantes Sociology Center) ; caroline.mazaud@univ-nantes.fr

(1) Created in 1997, the FNPCA (Fonds national de promotion et de communication de l'artisanat) is a public organization originally placed under the oversight of the ministry responsible for medium and small businesses, commerce, and the trades. Financed by a mandatory tax on the businesses it serves, it is jointly directed by the Chamber of Métiers and Trades (Chambre des métiers et de l'artisanat), professional organizations, and the State.
The trades sector is thus a lever for employment. Indeed, in 2007 there were 920,000 "artisanal" (small trade-based) businesses ${ }^{(2)}$ in France, representing about a third of French businesses. (3) In 2004 , at the time I began this study, nearly $40 \%$ of trade businesses were run by a tradesman over the age of 50. This demographic turn is a godsend for those struggling on the job market who might find a place in the sector. In addition, if the sector employs 2.5 million people, nearly half of trade businesses have no employees, thus representing a significant reservoir of potential jobs.

Accordingly, the Loi du 5 juillet 1996 relative to the development and promotion of commerce and trades (known as the Raffarin Law) stated its ambition in the very first article: that these two sectors

(2) The terms "trade-based business" or "business in the trades" are our translations of the term "entreprise artisanale" under French law, retaining its implications for the type of activity practiced as well as the scale of the business. A business is considered "artisanal" if it had fewer than ten employees when it registered with the Digital Métiers Repertory (RIM, Répertoire Informatique des Métiers,) and independently practices a primary or secondary professional activity in production, transformation, repair, or services in a field falling under the occupational categories classified as "artisanat" (of which there are over 250 defined by decree, ranging from butchering to computer repair to taxi driver). Given the wide range of occupations under this definition, we chose to translate "artisanat" as "the trades" instead, although the adjective "artisanal" was retained when appropriate, especially in describing the idealtype. By extension, "tradesperson" here is synonymous with "small business owner."

(3) Sources: RIM, January 1 of that year. Data available on the website of the Union professionnelle artisanale (http://www. upa.fr/artisanat-en-chiffres/entreprises-artisanales.html?upaPu blic $=810$ eafac $109 \mathrm{~b} 9710 \mathrm{fcf} 5 \mathrm{f} 0540 \mathrm{c} 08 \mathrm{cec} 3$ ). 
"should contribute to job development."(4) This law thus knocked down several barriers to entry, henceforth allowing more people to set themselves up in business. If, in the name of consumer protection, it requires formal qualifications for the practice of certain manual trades, the law also allows the owner to escape from this requirement if he or she has at least one full-time employee who holds the qualification in his or her place. Put another way, every potential business owner today may run a small business in a trade without holding the qualification for the trade so long as he or she employs someone holding this specific skill. In addition, the legal threshold for the number of allowable employees can be worked around by legal means. Since 1995 a right known as droit de suite allows, under certain conditions, owners of businesses in the trades with 10 or more employees to remain registered in the RIM, ${ }^{(5)}$ so that businesses employing 50, 100, or even more employees may still be considered "artisanal" alongside those in the official category of "very small businesses" (Très petites entreprises, or TPE; that is, with under 10 employees).

If the legislation nullified the two main criteria defining business in the trades, the owner's professional qualifications, and the number of employees he or she can employ, and since it was accompanied by a policy supporting the creation and development of small and medium businesses (petites et moyennes entreprises, or PME, with up to 250 employees) ${ }^{(6)}$ we might reasonably wonder if the profile of tradesmen has changed. Has the widening of the definition of tradesman led the arrival of new kinds of owners? What characterizes the organization of labor in the workplace today? Our project is not strictly deterministic, assuming that legislative changes would have induced the transformation of the group and its practices; instead, we observe the reality of the evolutions that are underway to comprehend if (and how) the legislative framework reflects a singular socio-economic context. To answer these questions, we will start with Bernard ZARCA's ideal-type model for "artisanat" (1986), based on the most complete sociological research on tradesmen as a group dating to the 1970s and 1980s. Only a handful of trades have been studied since, and there has been no overarching sociological work on the group as a whole, across occupations, in thirty years. Other disciplines have turned their attention to small independent businesses, however. Among them we retain the

(4) Loi 96-603 du 5 juillet 1996 relative au développement et à la promotion du commerce et de l'artisanat, article 1er, al, JORF, 6 juillet 1996, p. 10199.

(5) Décret 95-1287 du 14 décembre 1995.

(6) We are thinking of all the laws aiming to reduce official formalities for business creation, such as the 1994 Madelin Law, allowing prospective new business owners to file with a single application. More recently, the Dutreil Laws of 2003 and 2005 in favor of PMEs proposed targeted measures that, in the perspective of job creation, also aim to facilitate starting new businesses and taking over established ones. historical studies of Claire ZALC (2010), focusing particularly on small merchants of foreign origin, and Cédric PERrin (2007), studying the economic history of tradesmen. Although they shed light on small independent business owners, their studies do not go past the 1970s, the moment when sociology stopped taking this group as object of study. Today the trades as a whole are primarily covered by management sciences -but without paying attention to particular occupations. Management sciences' increasing interest in TPEs reflects the economic and demographic context that pushes them to examine practical solutions for business counseling and "modernization." They privilege the themes of their roles in innovation, human resources strategies, and transfer of established businesses, indicating that it is not so much the tradesmen that interest researchers as their businesses. The owners' social origins as well as their socio-professional and general family trajectories are usually ignored, to the point of sometimes making it impossible to understand how they achieved tradesman status or why they made certain business management choices. The sociological project undertaken here (see Box) will, to the contrary, consider the tradesmen's trajectories of mobility and the culture that they bear. Without neglecting the contributions of certain works in management, especially Katia Richomme's illuminating summary (2000), ZARCA's ideal-type model seems the most relevant for sociologically comprehending the evolution of the culture of trades and the potential transformations of the social group of tradesmen. From this ideal-type we retain two essential points defining the "essence" of practicing a trade: its specific division of labor and the singular social agenda of its members. This starting point will allow us in the second part of the article to put today's observed reality into perspective with the transformations that have taken place over the past thirty years.

\section{The Tradesman Ideal-Type}

\section{The Organization of Work in the Trades}

\section{A Division of Labor by Age Group}

Based on Max Weber's ideal-type for artisans (1865), ZARCA (1986, p. 8) proposes a model allowing us to grasp "the cultural significance," the "spirit" of artisanal worlds in the trades. Accordingly, one of its essential characteristics is found in the division of labor. The social division of ideal-type artisanal work is defined as a division in four successive ages. The first age, corresponding to primary socialization, is that of "the production of primary dispositions." It demonstrates the determinant role played by the class ethos in recruiting of future tradesmen, "where the relationship of parent-child / domination-dependence is homologous to the relationship master-apprentice / 


\section{Box \\ Methods}

This article is based on a vast study on the transformations of the trades over the past 30 years (MAZAUD 2009). In order to identify the changes in tradesmen's hiring strategies, practices, and representations, I collected the socio-professional trajectories of two populations, generally corresponding to (1) those who were leaving the tradesman group after having been in it for a long time, who had contributed to "making the trade," and (2) those who had recently successfully entered and established themselves in the group. I thus decided to exclude people who had started new businesses but had left the "artisanal" status shortly thereafter. To reach these populations, my sampling used a very precise protocol: I conducted an extraction from the RIM (Digital Métier Repertoire) in which I selected a population of "departures," aged 50 and up, and a population of "arrivals," registered in the RIM for three to five years, (1) in five towns in the administrative department of Loire-Atlantique (western France) selected for the variety of situations they offer (in demographic terms and according to activity sectors). Privileging the local scale, I went to meet these tradesmen and interviewed all that agreed to see me. (2) Without assuming a strict replacement of the former group with the latter, I established comparisons to give a view of the overarching trends in the trades at this key moment when the baby-boomers are retiring (who generally correspond to the generation of tradesmen who established themselves in the 1970s, those studied by ZARCA). I do not claim that the interviews presented here are statistically representative of tradesmen, but were chosen to illuminate the diversity of this group undergoing change.

Consequently, the four cases on which I base the demonstration correspond to four business owners whose trajectories exemplify the heterogeneity of the ways one may arrive at the status of tradesman, as it is legally defined. Antoine Bernard (3) is the general director of the company Flexi-Rapid' in the greater Nantes area, employing around 300 people. Guy Martin, a marble mason by training who has also studied accounting and economics, took over a marble and undertaking business located in a small rural town in the north of the department. His company belongs to a group, which is itself part of a holding company. Sophie Marchand is a young beautician who, after two years of university, learned her trade by correspondence then in a supervised internship before setting herself up in her hometown, a mid-sized town in the department. Lastly, Bernard Boutet, a former banker-turned-baker, established himself in the same town after purchasing a bakery with 18 employees.

Fieldwork was conducted between 2005 and 2007, prior to the passage of the law "modernizing" the economy, Loi de modernisation de l'économie du 4 août 2008, which created the status of auto-entrepreneur (self-employed). If my research cannot take account of the consequences of this new status, which moreover we know has strongly transformed access to independent business ownership, (4) I can indicate that this law is in line with the previously described policies aiming to reduce unemployment through self-employment by lightening the formalities for business creation and in simplifying how social and income taxes are calculated and paid. It seems that this law further opens this occupational group to people changing careers from other sectors, and that it accelerates the rate at which non-viable businesses are eliminated (BARRUEL et al., 2012).

(1) Since there is significant turnover among tradesmen, the minimum threshold of three years guarantees a certain degree of "stability." We consider the first three years to be the most fragile, especially concerning financial management: since actual income is unknown the first year, social taxes are paid at a flat rate; the second year they are retroactively regularized (based on actual income), which is often fatal to a small business.

(2) $\mathrm{N}=89$.

(3) All names have been changed to preserve the anonymity of interviewees.

(4) This status applied to $46 \%$ of new trade-based businesses in Loire-Atlantique in 2011. Since April 1, 2010, a self-employed person whose main activity is a trade is required to register with the RIM.

domination-dependence." "The age of apprenticeship" that follows sees the acquisition of professional qualifications and the re-enforcement of previously acquired dispositions. Skills are developed in the third age, which is a time for accruing experience as a skilled worker. During this "age of the journeyman" (to be understood here as "employee of a tradesman"), professional skill accumulates and allows the worker to ultimately practice the trade in his or her own right. The status of tradesman is the last "age." Established thereafter on his or her own, owner of a production unit, it is now the tradesman's turn to contribute to the transmission of the trade by forming apprentices and potentially hiring additional employees to work by his or her side. The division of labor in tradesmen's workshops thus respects the organization of people in the trade by age group.

\section{A Common Exercise of the Métier}

In Zarca's model, there is no technical division of labor separating skilled worker and tradesman. They practice their occupation together. The employee is indeed not the only person to execute work; the employer himself is a worker qualified in the trade and actively participates in production work in the workshop, and is not just the general manager of his business who delegates productive tasks to his employees.

The shared, side-by-side practice of a trade that is a characteristic component of the artisanal division 
of labor ideal-type illuminates the relationships between people working in the trades, the technical aspect aside. Based on empirical data, ZARCA identified some relevant indicators that reveal the singularity of these relationships, such as using the familiar " $t u$ " form of address between employees and owners in trade businesses or the frequency of sharing drinks at the end of the work day. All this contributes to the creation and maintenance of what he calls a "complicity of métier" between members of the trades who share the same professional practice and adhere to the same norms of professional excellence.

\section{A Mastery of the Whole Fabrication Process}

"In the same production unit, the métier-based division of labor is such that each worker is not in charge of one aspect of the fabrication of the work entrusted to him, but all of these operations," ZARCA explains (1986, p. 12), continuing his ideal-type description of artisanal work. Thus, employees and employers, without distinction of status, master the entire fabrication process without task specialization. This is a major characteristic of the trades that distinguishes them from industry. Industrial work is more hierarchical, the managers or owners do not do manual work themselves, and workers are in charge of a limited task without mastering the whole fabrication process. In such a configuration, and contrary to what happens in workshops in the trades, no industry-wide "complicity of métier" can develop, across participants of all statuses.

\section{A Unique Socio-Professional Agenda}

Because the employer is a former employee in the trade and every employee a potential employer, ZARCA states the trades are forming "an ordered structure of positions that every participant has occupied, is occupying, and will occupy with high enough objective probability that his hopes may even have a meaningful effect on the definition of his current position" (1986, pp. 14-15). Put another way, the similarity of the socio-professional progression of people working in the trades has consequences on how they imagine themselves at different ages and occupy a succession of positions, tending toward the status of tradesman.

\section{An Identical Norm for Knowledge Acquisition}

The norm of knowledge acquisition takes the form of training alternating between an apprentice training center (CFA, Centre de formation $d$ 'apprentis) and supervised work under a skilled master in a business. It is capped with acquisition of a qualification in the trade, a certificate of professional aptitude (CAP, Certificat d'aptitude professionnelle) in most cases. The person trained in the trade then develops his or her skills over time through a variety of professional experiences as a skilled manual worker, eventually managing to practice the trade independently.

In the journeyman-based training model, the foundation for the knowledge-acquisition norm, the rising tradesman accumulates knowledge and techniques that can only be gathered by regularly changing employers. More than simple instruction in professional gestures and knowledge, journeymanship, the historical basis of the organization of workers in the trade, also trains the individual by instilling a sense of duty and moral values such as honesty, being true to oneself and one's engagements, rigor, and respect (GUÉDEZ, 1994).

\section{The Ideal of Setting Oneself $U p$ in Business and Plans for Social Mobility}

The socio-professional ideal of employees in the trades as described by ZARCA lies in the plan to set oneself up in business on one's own. Since professional ascension, like social ascension, is only possible through independence, the trade-worker's plans for mobility diverge from those of industrial workers. While the latter try to ascend by climbing positions in the same company, the worker in the trades, as we have described, multiplies professional experience by going "from boss to boss." These experiences serve not only to enrich his or her skills in the trade, but also allow him or her to garner recognition through the essential building of professional networks that could be sources of information, occasionally encourage plans for setting up his or her own business, and often provide material help in starting out. This desire for independence thus leads all members of the trades to follow the same model for social success.

\section{The Mirror of Identification, the Basis of Regulation of the Trades}

A sort of mirror of identification unites employer and employee in the trades: the former sees his own past in the latter, who in turn projects himself in the place of the former in the desired future. Measuring the gap between this ideal and the lived reality in the 1980 s, ZARCA states that even if it is less probable that a skilled worker will become an independent business owner than maintain employee status, this progression remains a behavioral norm because people skilled in a trade still hold the socio-professional ideal of starting their own businesses. And although employment conditions are worse in the trades than in industry (lower incomes, overtime often uncompensated), they are not fundamentally contested. The sociologist thus imagines the discourse of the worker-type in the trades: "I'm currently being exploited. But when I'm (if I was) boss I'll (I'd) do the same with my workers. I have nothing to criticize my boss for, because to succeed you've got to do what he does to me, and what I'd 
do to others. And these others could do the same to yet others..." (ZARCA, 1982, p. 215).

The mirror of identification obviously does not remotely reduce the reality of the relationship of subordination, but it allows us to comprehend the full complexity of the employee/employer relationship. ZARCA (1986, p. 20) indicates this clearly: it "does not exclude the unequal sharing of the fruit of labor between tradesmen and journeymen, whose livelihoods differ as their ages differ. But these exchanges come into balance at the generational scale. Each accepts to pay the price to become independent in his turn. Moreover, this unequal distribution is supplemented by arrangements that facilitate the absence of accounting for work hours and, more generally, for all explicit economic calculation." It is, then, indeed the ideal of setting up one's own business that leads to the moderation of income demands and subscription to the same model of social success that regulates relations within the trades.

\section{The Trades Today}

So where does this ideal-type model defining and regulating trade culture stand today? ZARCA himself demonstrated that the trades in the 1970s-80s were distancing themselves from this ideal by presenting a greater variety of actual cases. At the time, however, trade culture was still the basis of practices in the trades, while the legal framework limited the number of allowable employees in such businesses. As we have seen, the legal context has transformed considerably since the 1980 s by expanding the definition of an "artisanal" business and reducing the impediments to starting a new business. Institutions representing and defending tradesmen's interests have since multiplied and expanded their areas of expertise: starting with simple technical assistance, the Chambers of Métiers and the Trades have now adopted an active policy encouraging the economic development of trade-based businesses (BENOîT, 2001). In addition, representatives of the trades have launched a policy to raise the image of the trades for the general public, especially with the actions of the FNPCA, founded in 1997. The socio-economic context has been considerably transformed. The tradesmen interviewed in the $1970 \mathrm{~s}-80 \mathrm{~s}$ had for the most part gone on the job market, or set even themselves up in business, at the end of the prosperous 30-year period following the Second World War, a time of strong economic growth that was also generally favorable to ascendant social mobility, as analyzed by Nonna MAYER (1977), who found that the social group of laborers was the main source for future small independent business-owners. So does observation of tradesmen's practices and trajectories today allow us to highlight new characteristics?
Have other forms of labor division emerged over the past 30 years? Is the tradesman's norm of socio-professional progression challenged by new agendas? Is the generation of tradesmen over 50 giving way to new profiles of tradesmen?

\section{A Redefined Division of Labor}

\section{The Separation of Production and Management}

Tradesmen now devote more time to the management of their business than they used to, to the detriment of production tasks. This fact, observed by informants themselves, confirms the results of recent studies on various occupations in the trades (JAcQues-Jouvenot, TriPIER, 2004). Moreover, we know that the time devoted to management gradually increases as the number of employees in the business rises. Most of the tradesmen we met agree that it is difficult to maintain any productive activity when one has more than ten employees, and that time spent at the desk managing the business and client and supplier relations wins out over time in the workshop. And yet the trend is indeed toward rising employment in the trades and an increase in the average number of employees per business: data extracted from the RIM indicates that in the LoireAtlantique, the territory covered by this study, the number of businesses in the trades progressed by $17 \%$ between 2000 and 2010 . Over the same period, employment in the sector has increased by $24 \%$. (7) Put another way, the number of employees is progressing more rapidly than the number of businesses. Additionally, it should be pointed out that although the percentage of businesses in the trades employing over ten employees is still low (of the order of $7 \%$ of the sector), the total number of employees working in it is significant. In the Loire-Atlantique, in 2010, employees working in trade-based businesses of ten employees or more represented $46 \%$ of the total employment in the trades in the department. This means that the droit de suite, rights authorizing a business to stay registered with the RIM even if it goes over ten employees, allows about half of the jobs in the sector to officially fall under the definition of "artisanat," which would not have been the case 15 years earlier.

If we turn our attention to tradesmen's individual histories, we cannot help but notice that the share of time devoted to management has expanded over the course of their professional trajectories. A strong majority of the interviewed "departures" had followed the traditional progression -that is, an apprenticeship alternating with classroom time followed by several professional experiences as a skilled worker. Become tradesmen in their own

(7) The trend is the same at the national level: thus in France over 100,000 businesses were created in less than ten years, and over 500,000 additional jobs over the same period. 
right, they then developed their businesses by hiring ever more personnel. These tradesmen eventually left the productive activity to devote themselves exclusively (or nearly) to "management" or "desk work," to borrow a term commonly used amongst them. In addition, some newly established tradesmen (the "arrivals") never experience the productive exercise of the activity. They limit their work to managing the business -commercial, financial, and human resources management duties- and delegate all production to skilled workers.

\section{Decline of the Shared Practice of the Trade}

The increasing time owners devote to business management, to the point of even specializing in it, reduces the shared practice of the trade between tradesmen and their employees. The difference of status between employer and employees becomes more distinct, as the division of labor between people in the trades tends to be redefining itself roughly as follows: employees get the professional exercise of production, processing, repair, or service qualifying their activity as "artisanat," a "trade," and the employer gets the general leadership of the business: managing administrative tasks, accounting, the sales of products and services, prospection of new clients, and human resource management. Depending on business size, the owner may have all of these managerial duties in his charge, or may only retain overall strategic planning and delegate the other duties.

In the context of our study, for example, we interviewed the general director of a business of nearly 300 employees that is officially considered as "artisanat." Flexi-rapid' is a limited liability company (an SARL, société à responsabilité limitée) established in 1995 by three Nantes-area business owners. All at the head of companies using hydraulic hoses, they were subject to periodic constraints when these hoses broke down, due to the significant wait to get them repaired. They thus decided to position themselves on this distinctive niche by creating a business aimed at the market for urgent on-location flexible pipe and hose repair. They hired their first mechanical repairman, invested heavily in the business, "and then, the snowball got rolling," explains Antoine Bernard, the current general director of Flexi-rapid'. "The characteristic, it's that the three owners have never worked in the business," he continues, "Me, I arrived three of four months later." At first, the company's founders approached Antoine Bernard, freshly trained at the Chamber of Commerce and Industry, to conduct a study of the company's development potential in France. He was then hired to "pilot the business's development" starting on this innovative concept, this "niche": to have the mechanic intervene directly on site, taking the measurements of the piece to be replaced himself, manufacturing it on site, and installing it in the shortest possible delay. The process is thus made completely independent; all activity is directed remotely from the business's headquarters, which dispatches technicians scattered all over France who are localizable in real time thanks to a GPS system. Antoine Bernard explains his work in the business:

"The owner's role evolves a lot depending on the size of the business. That's the first point... And it develops depending considerably on where his sensibilities lie: an owner who's more sensitive to management will spend more time in his office looking at figures, while a sales-sensitive owner will spend more time with his clients, an owner who tends to be technical is going to spend his time verifying that everything's going well at the work sites, an owner with developer tendencies will spend his time trying to organize the shop so it'll grow the fastest possible. I'm rather developer and sales, ok?... So my role is mainly a role of guiding development."

This son of a bank employee who knew one of Flexi-rapid's founders personally is moreover at the head of three other businesses of more modest scale, in entirely different sectors. Of course, this is an exceptional case because most of the configurations in trade-based businesses are in the middle, between the shared and simultaneous practice of a trade by all its practitioners, and the strict separation of production tasks from strategic business management. Nonetheless, with the multiplication of these tradebased businesses with ten-plus employees officially in the "artisanal" sector, bosses and employees are less and less likely to share the common practice of the trade that used to characterize their relationship.

\section{Diminishing Control of the Entire Fabrication Process}

Without necessarily becoming a norm, task specialization and the hierarchization of duties are developing even within trade workshops, prompting a decline in workers' control of the entire fabrication process and thus reducing their chances of starting their own businesses in the future.

In some sectors, workers are no longer trained in the knowledge of an entire trade, but only part of one. The example of hairdressing is instructive, with its distinction between "technicians" (specialists in coloring, highlighting, and permanents) and "hairdressers" (experts in shampooing, dressing, and styling). Anne-Chantal DuBERnet (2002), who studied this occupation, showed the extent to which the word "hairdresser" covers a range of real situations according to whether the tradesman is independent in his or her own right or owner of a franchised business. In the second case, the trade is divided into a series of tasks performed by "specialists." The case of automobile repair is also relevant here: mechanics, bodywork, maintenance, electrical systems, electronics, and so on. Additionally, even within these specialties one finds increasingly more procedures and repair materials that vary from 
one make to another, which further specializes the workers' know-how. The development of baking terminals likewise tends to specialize the tasks of the baking trade, since it is no longer a question of producing bread, from kneading through baking, but of cooking delivered frozen dough loaves -that is, only doing a part of the product's fabrication process.

It is the introduction of hierarchy through the hiring of team leaders, however, that most transforms the organization of work in the trades. In the 1980s, Christine JAEGER (1982, p. 157) confirmed that already in the trades, "the presence of a shop manager who divides up work and above all supervises the progress and pace of operations carried out by other workers is what most radically modifies the work process, and consequently the nature of the business." This was especially the case for what she called "small capitalist businesses," trade-based businesses employing six to nine people characterized by the presence of a shop or site manager who supervised the laborers' work. In these organizations, "not only is implementation work separated from that of organization and management, but the management tasks themselves are split into "technical' and 'administrative'," she explains (JAEGER, 1982, p. 185). Thus the business head most often manages the administrative services, while an employee, ranking between the workers and the owner, organizes and supervises the technical part of the work. While we concur with JAEGER on this observation, the predictions she made in the 1980s are far from the reality observed today, due to regulatory developments. Indeed, she held that these "little capitalist businesses" would have to leave the official trades sector particularly because their growth in employees would exclude them from registry with the RIM. Yet as we have seen, since 1995, the droit de suite allows businesses with over 10 employees to stay registered with the RIM. Moreover, JAEGER puts forward an economic argument to justify the departure of these "little capitalist businesses" from the trades sector: "the fiscal advantages linked to the taxation of real profits, then to the tax on companies, should incite the entrepreneur to transform the initial business into a company and to register with the commerce registry" (JAEGER, 1982, p. 191). Although it is indeed still in the interest of a growing sole proprietorship to formally become a company to take advantage of the company tax rate (which is lower than the income tax), it is not excluded from the RIM, because registration with the RIM today is not subject to a particular legal status, which means that "artisanal" businesses are not necessarily sole proprietorships: the share of companies among trade-based businesses is now even greater than that of sole proprietorships. ${ }^{(8)}$

(8) According to RIM data, sole proprietorships represent $48 \%$ of trade-based businesses in Loire-Atlantique.
Moreover, a business practicing a trade may have a double registration with the RIM and the Commerce and Companies Register (Registre $d u$ commerce et des sociétés, RCS): this is the case for those practicing a commercial activity and those taking the form of a company. Lastly it should be acknowledged that certain legal arrangements make it fiscally advantageous to stay registered with the RIM, while registration with the RCS would suffice to be in legal order; this is especially the case for rental management. Also, although these "small capitalist businesses" where shop managers oversee the productive work are distancing themselves from typical trade model, they do not have the deliberate intention of leaving the trades sector, and contribute to the official definition of the trades today.

\section{Opening Up Hiring}

\section{Ways of Acquiring Different Kinds of Knowledge}

In addition to the modifications of the division of labor in the trades, how owners come into the trades and are trained are also changing and becoming more varied. Overall the level of educational degrees is higher, especially for professional qualifications based on apprenticeship. Although "V-level" degrees ${ }^{(9)}$ remain the majority in the apprenticed population in the trades sector in LoireAtlantique $(58 \%$ in 2010), its share is declining, since only 15 years ago it was eight apprentices of ten. ${ }^{(10)}$ Beyond raising the level of apprentices' educational objectives, it should be pointed out that the higher one climbs in the hierarchy of apprenticeship-based degrees, the more one specializes. This observation sets the situation apart, then, from the apprentice group homogeneity described by ZARCA, a socializing step along the socio-professional career of someone skilled in a trade: today, the levels are varied, the specializations many, and the apprentices from diverse social and educational backgrounds (MOREAU, 2003). Even if apprenticeship as described by ZARCA remains dominant, it is gradually weakening.

In addition to that, formal training is no longer completed at the end of apprenticeship. Tradesmen often train themselves all along their professional careers, especially in business management, sales, or human resources management. Some people skilled in a trade who followed the classic apprenticeship-based training system opt for continuing education. This is the case for Guy Martin, owner of a marble-masonry and undertaking business who we met during our study. The son of marble masons

(9) That is, qualifications inferior to that of the baccalauréat (the national competitive, degree-granting exam capping the end of secondary education and opening the door to university), such as the CAP and BEP, (Brevet d'études professionnelles). (10) Source: Chamber of Métiers and the Trades of the Pays de la Loire, January 11995 and 2010. 
in the Limousin region, Guy Martin explains his trajectory by the desire to get out of the trades, as his own father had encouraged him to do. From the youngest age, he advised him to "see other things," "to know his trade." So Guy Martin takes an apprenticeship, not with his father as some do, but apprenticing to another boss in alternation with course work in a CFA near Grenoble, half way across the country. This initial training is not, however, considered to be its own end. He gets a CAP degree in marble masonry, and upon returning to the Limousin, he works a bit with his father while taking "night classes" at a school in Limoges where he learns accounting and economic sciences. After his mandatory military service, Guy Martin comes back to work once again in the family business (for a total of three years), again taking "night classes". But his father does not want him to stay: "He wanted me to see other things. "So the young marble mason launches himself into supplementary training that allows him to acquire a general knowledge of all the professions "around death," especially those of undertaker (which is starting to attract some marble masons whose stone-cutting activity is challenged by imported granite) and embalming (which he would go to England to study). He starts an independent embalming practice and teaches it in a school. Guy Martin then joins an undertaking group (composed of eight agencies located in two French administrative departments) which itself belongs to a holding company (a public limited company [SA, société anonyme] with 700 sales points across France). Guy Martin buys a sizeable family-run undertaking business in the Loire-Atlantique that is in the group, and he transforms its business structure into a limited liability partnership (SARL, Société à responsibilité limitée). With the support of the company, he captures the market share of small marble mason workshops, which he gradually buys up. The integration of these companies nonetheless leaves each of them legally independent. Indeed, each marble masonry business continues to be registered with the RIM, because of the small number of initial employees. Guy Martin's role in the group and at the head of his SARL, thanks to his many skills and his knowledge of the sector (and not only his practice of the trade), is to assure the transfer between those ceding the businesses and the young new arrivals charged with taking over responsibilities in the various former independent businesses-becomeagencies of the group. His job is also to supervise this team and teach them the commercial strategies he has acquired: to buy small marble mason shops by previously identifying the profitable areas for establishing an agency for the group. So he encourages the young members of the group to work on the mortality tables ("You've got to go to towns with an aging population") and to observe the presence or absence of retirement homes and elder home care policies. Guy Martin also teaches them to get close to hospitals and ambulance companies who have, as he puts it, "primary material".

"Excuse me for talking this way... but who has the primary material? It's the ambulance company. He transports them like a taxi at the beginning, he transports them lying down sick. And if he says that he does undertaking, inevitably... if everything went well, the family knows him, he'll ensure the undertaking! So... And if in addition, behind that, there's a funeral monument business able to do his vault for him, to give him all kinds of advice, well, he does everything."

The owner also teaches his team members to offer the clientele various products and services, such as funeral contracts. Lastly, he trains embalmers internally to limit costly subcontracting. "Today there's a majority of small family operations," but "in a few decades, there'll only be big groups," he predicts, himself contributing to the transformation of the profession by acquiring and putting to use the wide-ranging capabilities of his own skill-set in the occupation.

\section{The Emergence of Incomers with Varying Life Courses: University Drop-Outs and Former White-Collars}

Beyond the diversification of training and how it may be acquired, the trades are being transformed by the arrival of people changing careers. Without initially going through the traditional norm of knowledge acquisition, these newcomers do not necessarily have qualifications in the trade and have not always practiced their techniques as a skilled worker. Often having gone through university or a business school, they base themselves more on theoretical competences than skills in a specific trade. Setting themselves up in business is not the result of belonging to a trades culture or a collectively shared ideal of social success, but of a second choice, a career change.

A share of these newcomers fall under what the personnel of the Chamber of Métiers and Trades referred to in interviews as a "public of university failure." These young newcomers belong to what's known as the " $80 \%$ with the $b a c$ " generation. The " $80 \%$ " program, launched in 1985 to democratize higher educational qualifications, was supposed to apply to all tracks of the baccalauréat examination and diploma (commonly called the "bac"). But in reality it favored the general and technical tracks to the detriment of the professional track. The policy was followed by a rapid influx of students in the university system and, in parallel, a high undergraduate failure rate for those from the most modest backgrounds and the least prepared of this generation (BEAUD, 2002). Today some of these "drop-outs" reorient themselves toward the trades, where they start apprenticeships. This 
is the case for Sophie Marchand, a young beautician met during the study. After obtaining a bac diploma in economic and social sciences in 1997, she started university in sociology with the goal of becoming a teacher. The daughter of a mason and a housekeeper, she is the only child in the family to have pursued higher studies. After two years at the university, Sophie Marchand admits, "I couldn't see the end of the road!" Though she wanted to reorient herself, she mostly wanted to avoid entering the job market without professional qualifications, because summer jobs had given her a glimpse of the working world for those without a diploma:

'Since I knew I wasn't going to continue in soc', I said to myself, I can't leave without anything. I'd done the factory as a summer job and I told myself never, never will I stay without any education! Because the factory, it's, you know... It's fine, but it's not satisfying. That's what pushed me a little to get busy and find myself another path."

She chose beauty. In fact while she was still a student, a school opened on the street where she lived. This prompted her to find out about training options in this field. "So, starting there, I started over from zero," she explains. At 19 years old she took a correspondence course for a year, then a two-month practical course. She then had to do a practicum internship in a business: she asked a beautician in her hometown, who took her on as intern then apprentice. Although the CAP degree usually takes two years, the beauty school she contacted thought that given her educational history, one year was enough. Sophie Marchand then pursued an apprenticeship in alternation with course work and continued exploring the occupation by preparing for a vocational certificate (brevet professionnel) while still working for the same employer. Two months after receiving her degree, she bought the business where she was trained. Like Sophie Marchand, young tradesmen who quit university have not initially followed training in a trade. With their reorientation, though, they take wholeheartedly to the socio-professional progression traditional to the trades (apprenticeship in the trade alternating studies and on-the-job experience, accumulating experiences through the status of employee then establishing one's own business), but at a later age, and at a faster pace.

Other kinds of career changes may lead to the trades: former white-collar workers from the industrial or service sectors quit their jobs to start and manage their own trade-based businesses, but without participating in its productive activity. According to ZARCA (1988), in the 1970s-80s, the young incomers that shook up the traditional trades were trained in technical schools, not through apprenticeship. They went into the trades by participating in innovative activities: more conceptual than manual, these incomers were more technicians than managers, which is to say that they were not like some owners I met who have no skills in the trade and delegate all productive tasks, such as Bernard Boutet. After initial training in accounting, Bernard Boutet earns his commercial teaching certificate (brevet d'enseignement commercial). From there he starts a 33-year career at Crédit Lyonnais bank. His trajectory is characterized by geographical, professional, and social mobility. Bernard Boutet thus starts his career in accounting before moving on to management audits and computing and ending up in the asset-liability management service. Yet this professional ascension does not offer him the conditions for his complete satisfaction. He feels like he is in a dominated position in an environment mainly composed of people who were trained in prestigious schools, ENA (the highly exclusive National School for Administration) and HEC School of Management (an elite business school). With his lower educational level (level IV, limited post-secondary qualifications), and despite his professional promotion, he confesses, "I was the ugly duckling!" When the bank announces a restructuring plan that does not concern his position, he nonetheless decides to seize the opportunity to change careers. The timing seems opportune because his wife, an employee of the same bank, is directly affected by the restructuring. Most of all, he wants to leave his job in a big business to become independent. Bernard Boutet looks at the classic kinds of career change he had seen over the course of his career at the bank: hotels, bars, restaurants, bed and breakfasts, etc. He thinks about going into computing or accounting, but ultimately decides on baking, especially because "it's an occupation where you earn a good living without any major risk." He attends trade fairs to explore his options, and at a fair he discovers the "Éric Kayser" franchise brand, with which he signs a "skill transmission contract." In exchange Bernard Boutet agrees to send the franchise $6 \%$ of his turnover for eight years, about 65,000 euros per year. He then proceeds to build his project, buying a pre-existing business and leasing equipment. His financing, a total of 4.5 million francs at the time, ${ }^{(11)}$ consists of two career-change subsidies (his and his wife's), a bank loan, and "a little help" from the franchise to "make the budget." At the same time Bernard Boutet takes a short adult training course at the Ferrandi culinary school (associated with the Chamber of Commerce and Industry), which offers three-month intensive training courses leading to qualifications. But he does not want to test for a CAP degree at the conclusion of the course because he does not need the degree to perform his job as manager. For him, the knowledge acquired in training only "gives the general idea," "to not be ignorant in front of the employees." Nathalie Scala-Riondet (2006, pp. 250-256) has similarly

(11) That is, approximately 686,000 euros, a considerable sum for setting up in a trade. 
demonstrated that these accelerated courses do not teach the trade of baker, but the role of a business head. Indeed, Bernard Boutet's desire, made clear from the outset, is to create a business that employs enough manpower to compensate for his own lack of skill and experience in bread production and thus to delegate production to his employees. Finally at the head of his bakery, he transforms the traditional practices of the baker's trade, as we will see shortly, and sums up the usual progression from apprentice status to boss thusly: "I was an apprentice, and the worker gave me a hard time. So I can't wait until I'm a worker to give the apprentice a hard time. And if ever I get to be boss, that way, I'll give them both a hard time! The classic pattern, there it is!" He adds, "You've got to know that exists!" and "I hadn't imagined it was so bad!" When he took it over, the business had had four employees: he only keeps one, a sales clerk, and gradually hires new employees, especially through the franchise. "With the old baker," he says, "it was Zola," like the 19 th $^{\text {th }}$ century. For this business owner, then, it had to change, no question of it "staying in the patterns of bakers" who too often learn their trade after a failure at school. He would also hire people from outside the profession, like one employee educated in agronomy, initially hired to do sales but promoted to head baker. Bernard Boutet multiplies hires (up to 18 employees) and establishes a hierarchy by hiring a head baker and a head pastry chef. He modifies the bakers' working hours, who henceforth would no longer work at night, and imposes the use of "growth chambers" to accelerate the fermentation of bread dough. He actively incites his employees to go into the shop, in a "customer spirit," but he laments, "a baker, making him understand he's also a salesman...!" In the shop, Bernard Boutet imposes background music and organizes tastings and open houses. He had already set up the space so as to make the oven visible from the shop ("we knocked everything down"). The owner makes it policy to diversify the product range for niches deemed to be "booming." This is how he justifies the introduction of hemp bread, which "responds to an existing reality, dietary, ecological. Hemp's got a lot of omegas!" The launch of new products calls on the imagination and the senses: "selling flavor, aroma..." All these changes in professional practices do not go entirely smoothly, and the employees have trouble accepting what they see as a challenge to their skills and culture in the trade: Bernard Boutet declares he has signed over 100 work contracts in seven years and to have been called before the labor relations board three times (for psychological harassment in particular). And even if he has since sold his business, it should be noted that the practices he put in place are not disappearing with the new business owner. Proposed by the franchise, his successor has a profile similar to that of Bernard Boutet: though he is somewhat younger, he is a former employee in the grocery industry hoping to be heavily supervised by the franchise with which he signed a contract, and is not a skilled tradesman.

While the desire for social ascension guided the socio-professional trajectories of apprentices then workers in a given trade, the strategies are modified with the diversifying life courses of people coming into the trades today. Career-changers setting themselves up in business use it more as a safety net than a means to social ascension. Elsewhere I have developed the fact that new arrivals are less likely to have histories in labor, in either their social origins or work histories, and are more frequently from middle- or upper-class backgrounds (MAZAUD, 2009). When one considers the reasons for which new arrivals come to the trades and the context in which they set themselves up, one notices that their professional bifurcations systematically show that the career-changers were disenchanted with their previous professional universe. The university path chosen by Sophie Marchand, which was supposed to bring her to the teaching profession, no longer makes sense to her after two years of study, without a degree to show for it. As for Bernard Boutet, he showed the desire to leave a big business, shaken by a restructuring plan, in which he had spent his entire career as an employee. Thus these career-changers desperately hope to change their working conditions, their jobs, and often their lives. They defend their desire for independence, their will to take decisions alone, and the possibility to organize their work and personal times as they see fit. These career-changers express their feelings after-the-fact, however, which is to say, after having set themselves up on their own, and their desire for change is doubtlessly not the only reason for their move to independence, in fact the result of several factors. As Claire ZALC, who reconstructed the history of foreign merchants in France, rightly points out, "the notion of attraction, borrowed from psychologism, may bring about confusion"; these trajectories "cannot be equated to the realization of wants and desires" $(2010$, p. 15). The same context holds true for incomers setting up in the trades: tough socio-economic competition, manifesting itself in a tense employment market, indeed favors these career changes. This fact is part of a wider movement already described by Cédric PERRIN (2007): in times of crisis the number of people working in the trades sector increases and, inversely, the trades stop being appealing when the job market offers more satisfactory security. Thus, unemployment was behind many career-changes in the early 1940s, while the establishment of the social welfare system upon Liberation at the end of the war would distance candidates from going into trade-based businesses. The difficulties in finding their place on the employment market thus bring some disenchanted employees to invest in the trades today.

But disenchantment with the previous professional world or fear of the future in the face of a tight 
employment market could well remain solely in the domain of ideas if no triggering event sets off such a split. Nearly all the questioned career-changers went through a crisis, sometimes in the family, often at work (being laid off) before becoming a tradesman. For those who dropped out of university, failing exams could be the element that launches them in a new direction. At this key moment the plan to set up a business matures and takes concrete form, a plan that might have remained a simple daydream if nothing had happened to shake up the situation and force the person to make choices. This quote from an interview with the owner of a business selling and integrating computing solutions demonstrates this. He relates the moment when he got laid off and decided to start his own business:

"- At that moment, realization: do I take off for another company, or do I launch myself, as my own company?

- So you already had this idea in mind before you struck off on your own?

- Yes, it was more or less latent, but no particular event pushed me to do it. [...] As much as [being laid off] was a negative thing at the beginning, it became as much a positive thing precisely because it allowed me to do what I do today. While if they hadn't filed for bankruptcy, I would maybe still be with them as an employee."

Career-changers' orientation toward tradesman status is not the achievement of a trajectory driven by an ideal of running one's own business, but the means of finding or maintaining one's social position, not falling victim to a drop in social class. Independence is a safety net for individuals who, in salaried employment, could not (or could no longer) manage to hold a position corresponding to their initial training. By setting themselves up on their own, they assure themselves an intermediary position in the social hierarchy.

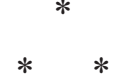

In the ideal-type model proposed by ZARCA, the shared practice of the trade and the proximity of employees' and employers' socio-professional agendas bring about a mutual identification among practitioners of the trades and regulate their behaviors. And yet the mirror of identification that unites them (each according to his or her status) starts to crack once the division of labor is altered with the separation of production and management, leading to a decline of the shared and simultaneous practice of the trade. This crack seems even deeper since the norms of knowledge acquisition have diversified and the group has come to include a public that had not initially aimed to work in the trades. Although we do not conclude that the end of the trades as we know them is nigh, as is too often the case, we can nonetheless signal that it is being "imbalanced" by threats to what used to be the basis of its uniqueness. New arrivals to the trades seem to scatter themselves more by the kind of duties they take on, between the productive skilled tradesman and the manager. The group of tradesmen, a splintered entity, brings together individuals from varied socio-professional backgrounds and paths. Less frequently driven by a desire for social ascension, the career-changers who join the trades today adopt a status first, before choosing a trade, in order to avoid the drop in social class that threatens them. These developments take place as the entire structure of the trades is transforming, for indeed, the share of production-based trades is declining in favor of trades in construction and services (MAZAUD, 2009). 


\section{Bibliography}

BARRUel F. et al. (2012), «Trois auto-entrepreneurs sur quatre n'auraient pas créé d'entreprise sans ce régime», Insee Première, $\mathrm{n}^{\circ} 1388$.

BEAUd S. (2002), 80\% au bac... et après? Les enfants de la démocratisation scolaire, Paris, La Découverte.

BENOîT C. (2001), Les chambres de métiers face aux mutations de l'artisanat, mémoire de sciences politiques, IEP Grenoble.

Boutillier S. (2007), «Politique publique et création d'entreprise, une analyse contemporaine du capitalisme aménagé de J. M. Keynes», Cahiers du Lab. RII, Documents de travail, $\mathrm{n}^{\circ} 154$.

DuBERNET A.-C. (2002), «Des "métiers traditionnels aux vrais métiers" », in Piotet F. (dir.), La révolution des métiers, Paris, Presses universitaires de France, pp. 25-52.

Durand M., Frémont J.-P. (1979), L'artisanat en France, Paris, Presses universitaires de France.

GuÉDEZ A. (1994), Compagnonnage et apprentissage, Paris, Presses universitaires de France.

JACQues-Jouvenot D., TRIPIER P. (coord.) (2004), «Loin des mégalopoles, couples et travail indépendant», Cahiers du genre, $\mathrm{n}^{\circ} 37$.

JAEGER C. (1982), Artisanat et capitalisme, l'envers de la roue de l'histoire, Paris, Payot.

MAYer N. (1977), «Une filière de mobilité ouvrière : l'accès à la petite entreprise artisanale et commerciale», Revue française de sociologie, vol. 18, $\mathrm{n}^{\circ}$ 1, pp. 25-45.
Mazaud C. (2009), Entre le métier et l'entreprise, renouvellement et transformations de l'artisanat français, thèse de doctorat : sociologie, université de Nantes.

Moreau G. (2003), Le monde apprenti, Paris, La Dispute.

Perrin C. (2007), Entre glorification et abandon, l'État et les artisans en France (1938-1970), Paris, Comité pour l'histoire économique et financière de la France.

Richомme K. (2000), Contribution à la compréhension du système de gestion des entreprises artisanales, thèse de doctorat: sciences de gestion, université Montpellier 1.

Scala-Riondet N. (2006), Des formations aux professions dans un secteur artisanal : la boulangerie, thèse de doctorat : sociologie, université Paris 8.

Weber M. (1965), Essais sur la théorie de la science, Paris, Plon.

ZaLC C. (2010), Melting shops, une histoire des commerçants étrangers en France, Paris, Perrin.

ZARCA B. (1982), «La spécificité de l'artisanat au sein des classes moyennes traditionnelles», Revue française de sciences politiques, vol. 32, $\mathrm{n}^{\circ} 2$, pp. 210-222.

ZARCA B. (1986), L'artisanat français: du métier traditionnel au groupe social, Paris, Economica.

ZARCA B. (1988), «Identité de métier et identité artisanale», Revue française de sociologie, vol. 29, $\mathrm{n}^{\circ} 2$, pp. 247-273. 